\title{
Measuring the (income) effect of disability insurance generosity on labour market participation
}

Citation for published version (APA):

Marie, O., \& Vall Castello, J. (2011). Measuring the (income) effect of disability insurance generosity on labour market participation. METEOR, Maastricht University School of Business and Economics. METEOR Research Memorandum No. 050 https://doi.org/10.26481/umamet.2011050

Document status and date:

Published: 01/01/2011

DOI:

10.26481/umamet.2011050

Document Version:

Publisher's PDF, also known as Version of record

\section{Please check the document version of this publication:}

- A submitted manuscript is the version of the article upon submission and before peer-review. There can be important differences between the submitted version and the official published version of record.

People interested in the research are advised to contact the author for the final version of the publication, or visit the DOI to the publisher's website.

- The final author version and the galley proof are versions of the publication after peer review.

- The final published version features the final layout of the paper including the volume, issue and page numbers.

Link to publication

\footnotetext{
General rights rights.

- You may freely distribute the URL identifying the publication in the public portal. please follow below link for the End User Agreement:

www.umlib.nl/taverne-license

Take down policy

If you believe that this document breaches copyright please contact us at:

repository@maastrichtuniversity.nl

providing details and we will investigate your claim.
}

Copyright and moral rights for the publications made accessible in the public portal are retained by the authors and/or other copyright owners and it is a condition of accessing publications that users recognise and abide by the legal requirements associated with these

- Users may download and print one copy of any publication from the public portal for the purpose of private study or research.

- You may not further distribute the material or use it for any profit-making activity or commercial gain

If the publication is distributed under the terms of Article $25 \mathrm{fa}$ of the Dutch Copyright Act, indicated by the "Taverne" license above, 
Olivier Marie, Judit Vall Castello

Measuring the (I ncome) Effect of Disability I nsurance Generosity on Labour Market Participation

$\mathrm{RM} / 11 / 050$

\section{METEOR}

Maastricht University School of Business and Economics

Maastricht Research School of Economics

of Technology and Organization

P.O. Box 616

NL - 6200 MD Maastricht

The Netherlands 


\title{
Measuring the (Income) Effect of Disability Insurance Generosity on Labour Market Participation
}

\author{
Olivier Marie ${ }^{\mathrm{a}, \mathrm{b}}$ and Judit Vall Castello ${ }^{\text {cd }}$
}

$a$ - Research Centre for Education and the Labour Market (ROA), Maastricht University, P.O. Box 616, 6200 MD Maastricht, The Netherlands. o.marie@maastrichtuniversity.nl

$b$ - Centre for Economic Performance (CEP), London School of Economics, Houghton Street, WC2A 2AE London, United Kingdom. o.marie@lse.ac.uk

$c$ - Department of Economics, Universitat de Girona, 17071, Spain. Telephone: (34)972-418781. Fax: (34)972-418032.judit.vall@udg.edu

$d$ - Research Centre for Economy and Health (CRES), Universitat Pompeu Fabra, Ramon Trias Fargas 25-27, 08005, Barcelona, Spain. judit.vall@upf.edu 


\begin{abstract}
We analyze the employment effect of a law that provides for a 36 percent increase in the generosity of disability insurance (DI) for claimants who are, as a result of their lack of skills and of the labour market conditions they face, deemed unlikely to find a job. The selection process for treatment is therefore conditional on having a low probability of employment, making evaluation of its effect intrinsically difficult. We exploit the fact that the benefit increase is only available to individuals aged 55 or older, estimating its impact using a regression discontinuity approach. Our first results indicate a large drop in employment for disabled individuals who receive the increase in the benefit. Testing for the linearity of covariates around the eligibility age threshold reveals that the age at which individuals start claiming DI is not continuous: the benefit increase appears to accelerate the entry rate of individuals aged 55 or over. We obtain new estimates excluding this group of claimants, and find that the policy decreases the employment probability by 8 percent. We conclude that the observed DI generosity elasticity of 0.22 on labour market participation is mostly due to income effects since benefit receipt is not work contingent in the system studied.
\end{abstract}

Keywords:

Disability Insurance; Labour Market Participation; Income Effect; Regression Discontinuity. 


\section{Introduction}

Disabled individuals have incomes which are on average almost 15 percent lower than the rest of the population in developed Western economies, and only 70 percent of the mean in the United States (OECD 2009). This is despite a very substantial documented increase in disability insurance (DI) availability and generosity in recent decades (Autor and Duggan, 2006; OECD, 2003). The cost of expanding this sort of protection program has so far been outweighed by the sustained economic growth of the past twenty years ${ }^{1}$. However, with the fallouts of the financial crisis on government spending limitations, the burden of DI on the public purse will certainly come under renewed criticism. The recurring principal argument for reform of the disability benefit system has, however, not been its cost, but rather its potential perverse incentive on the labour market participation (LMP) of certain groups of individuals.

The relationship between DI availability and generosity and LMP is an intrinsically difficult question to answer. The main criterion for eligibility is always broadly defined as having a physical or mental impairment that prevents a person from engaging in substantial gainful activity. This means that the selection process into DI is strongly dependent on an individual having a low probability of participating in the labour market, making the claim and work decisions highly endogenous. Any evaluation of a disability benefit program must therefore carefully deal with this endogeneity issue in order not to over-estimate its impact on the labour market behaviour of recipients. There is now an influential literature exploring this relationship using various methodological approaches to the problem, and we review it in the next section of this paper. The almost universal consensus is that DI has a very negative effect on the attachment to the labour market of eligible claimants. The remaining debate seems to be mostly about the size of this effect.

Autor and Duggan $\left(2007,2008^{2}\right.$ ) are among the few that have recently focused on better understanding the mechanisms behind the behavioural response of DI claimants. Their main argument is that it could be due not only to the usually suggested distortionary substitution effect on incentives, but also to a non-distortionary income effect. The latter interpretation would imply

\footnotetext{
${ }^{1}$ Despite increases in the number of claimants and the average generosity of these benefits, the good economic performance of the economy has meant that the cost of DI has remained stable since the early 1990s in OECD countries at around an average of 1.3 per cent of GDP.

${ }^{2}$ We would like to thank these authors for making their 2008 unpublished report to the Social Security Administration available to us.
} 
that the observed reduction in labour supply is not a deadweight loss, and is providing the right amount of transfer income in order for disabled individuals not to have to work above their substantial gainful activity level. These authors have attempted to empirically measure the importance of the income effect channel on LMP by using one of the few such DI programs in the U.S. which is not provided exclusively on a work-contingent basis (Department of Veterans' Affairs Disability Compensation Program (VDC)). Their findings suggest a large income effect on near elderly males, but these results are only tentative because of data limitations. We propose here to investigate this issue by exploiting certain unique features of the DI system in Spain.

The Spanish insurance system for disabled individuals is first characterized by a low and relatively stable recipiency rate by international standards ${ }^{3}$. Those who are eligible then receive monthly transfers which are fixed to a certain proportion of their wage level prior to the disability (i.e. it is a contributory insurance scheme ${ }^{4}$ ); the payments are secured until moving to retirement pensions at the age of 65. These replacement rates are 55 or 75 percent for partial disability claimants, 100 percent for total disability, and 150 percent for severe disability claimants. Crucially, the benefit amount is contingent on having employment income, unlike many other countries such as the United States. Another interesting feature of the Spanish system is that certain claimants of partial disability benefits are eligible to receive a 36 percent increase in the amount of benefits when they turn 55 years old. This is granted to DI recipients with lower skill levels who are exposed to local labour market conditions which are deemed to make it difficult for the recipients to find employment. The higher 75 percent replacement rate is granted to just under two thirds of partial disability claimants over the age threshold, and close to none before that. This particularity enables us to investigate the impact of this large increase in DI generosity on the LMP of near elderly individuals using a regression discontinuity approach.

We use a large representative sample of the Spanish population receiving disability benefits for which we have monthly administrative data on work and benefit history between 1996 and 2007. We focus our attention on partial disability recipients who are between 51 and 58 years old, and are able to identify the individuals who are treated with the benefit increase. Because of selection on low LMP probability, naïve OLS estimates of the treatment effect

\footnotetext{
${ }^{3}$ Only 4 percent of the population aged 20 to 64 receive disability benefits in Spain compared to an OECD average of 6 percent, which is the same number as in the United States (OECD 2007b, 2008, 2009)

${ }^{4}$ There is also a non-contributory disability benefits system but it is comparatively smaller in size (205,000 people received non-contributory disability pensions in Spain in 2007 as opposed to 868,000 that receive contributory disability pensions). We do not include the group of non-contributory pensioners in our analysis.
} 
logically generate a huge policy impact even after controlling for observable characteristics. When we consider more appropriate models that control for time invariant unobserved individual characteristics, we obtain estimates of the policy impact which are more than three times smaller. These may still be biased estimates because of the endogenous relationship between DI increases and LMP probability.

To justify our regression discontinuity (RD) approach, we first graphically inspect the behaviour of the treatment indicator (DI increase), covariates (gender, education, and age started claiming DI), and the outcome (LMP) around the age threshold. The first problem we note is that there is a jump in the proportion of individuals who enter the benefit rolls at age 55 or over, which could jeopardise the validity of using an RD design. We solve this problem by carrying on all the analysis on two different samples: all claimants, and an alternative sample which is restricted to those who entered DI before the age threshold. The graphs show a clear jump in treatment probability while other variables appear relatively smooth before and after the age cutoff, except perhaps the age at which recipients started claiming DI. There is a small apparent discontinuity in the probability of employment which needs to be tested for significance.

Our formal statistical RD approach first considers different age windows around the 55 year threshold. These results suggest that the increase in DI generosity is at least responsible for a three percentage point decrease in LMP. As a simple robustness check, we include covariates to the model, as these should not affect our RD estimates if they are smoothly distributed around the age threshold. This is not the case for age started claiming DI; when we turn to our restricted sample, we now find that increased benefit generosity reduces employment probability by one percentage point. We run experiments with placebo policies at age 54 for partial disability claimants and at age 55 for total disability ones. None of these groups experience changes in LMP around these cut-off ages which emphasizes the robustness of our results.

Our main results translate into an eight percent reduction in employment probability and an elasticity of DI generosity on LMP of 0.22 . They are in line with the findings from previous research on this subject, and especially the results from Gruber (2000). However, considering that benefit eligibility is not work-contingent in Spain, the observed impacts of DI generosity on LMP appears to be mainly due to an income effect, in line with the incentive mechanism put forward by Autor and Duggan (2007, 2008). We believe this paper is one of the first ones to 
strongly support this interpretation with an unambiguous evaluation of the impact of a non-work contingent DI benefit increase on the LMP behaviour of a general population of older workers ${ }^{5}$.

The rest of the paper is structured as follows: Section 2 gives an overview of the related literature on the impact of DI on LMP. Section 3 discusses the disability benefit system in Spain and the increase in DI generosity program. Section 4 describes the data and gives some descriptive statistics. Section 5 presents the methodology. Section 6 reports and discusses the results, and section 7 concludes.

\section{Related Literature}

Much of the literature on the work disincentive effect of permanent disability benefits is based on the analysis of the Social Security Disability Insurance (SSDI) program in the United States. Labour force participation rates for older males in the U.S. have fallen during the last three decades, and an extensive body of research has emerged that attempts to link this evolution with the growth of the disability insurance program. The argument is based on the high implicit marginal tax rate on earnings above a threshold (\$940/month in 2008) that is used for acceptance into the disability program ${ }^{6}$. It is widely understood that the current design of the program creates disincentives to work for disabled individuals, but there is still disagreement on the magnitude of these effects, the intrinsic mechanism behind them, and their contribution to the decrease in labour force participation of older Americans. The main problem encountered when trying to estimate the size of the disincentives to work resulting from the disability insurance system is the endogeneity of the receipt of disability benefits in a labour force participation equation. In order to obtain unbiased estimates, researchers have tried to use exogenous

\footnotetext{
${ }^{5}$ Two recent papers, Angrist et al (2010) and Boyle and Lahey (2010), find that disability benefit availability for Vietnam veterans, which is not work contingent, seems to reduce their labour force participation. However, as Autor et al (2011) point out, it is somehow difficult to disentangle the long term effect on health of "battle scars" (p. 3) from the effect of recent changes to this benefit program. We do not believe that this problem exists in this paper because the DI increase studied is both non-work contingent and is available to the general population of older workers.

${ }^{6}$ Applicants to the disability insurance system in the USA need to demonstrate that they did not work during the five months prior to the application. Moreover, once they start receiving the benefits, they cannot gain more than the threshold defined by the SGA. If they earn more than the SGA for more than nine months, benefits are terminated (Maestas and Yin, 2008). Livermore et al. (2009) estimate that employment rates of individuals receiving disability benefits are $9 \%$ in the U.S. (both SSI and DI beneficiaries). In Spain, where there are no legal limits to work for disabled individuals, these are surprisingly not that much higher and stand at $12 \%$. However, one must consider that overall activity rate of older individuals are on average much lower there.
} 
variations in the level of benefits, or to rely on econometric techniques that can account for this endogeneity.

In this line of research, Bound (1989) compares a sample of rejected and accepted DI beneficiaries, and estimates that the counterfactual labour force participation rate of disability recipients would have been 30 percentage points higher if they had not received the benefits. The validity of his estimates relies on the assumption that both groups are relatively similar in observed and unobserved characteristics, although he recognizes that rejected applicants are usually somewhat healthier than accepted applicants. Therefore, his estimates represent an "upper bound" of the potential labour force participation of DI receivers. Two more recent papers by Von Wachter, Song, and Manchester (2011) and Chen and Van Der Klaauw (2008) use a similar approach. The first of these papers uses a very rich longitudinal administrative database in order to replicate the results from Bound for workers aged 45-64, and to extend the analysis to younger workers aged 30-44, a group which has gained importance within the pool of DI applicants in the United States. Using as a counterfactual the employment rates of rejected applicants by impairment, industry and earnings group, their results suggest that economic conditions may have induced an important fraction of workers (especially younger workers) to apply for DI even if they are still able to work. The second of these papers by Chen and Van Der Klaauw (2008) focuses on the impact of the receipt of disability benefits for marginal applicants for which access to the disability system is only decided in a second stage of the eligibility process on the basis of vocational and age factors. For age, the cutoff points are set at 45, 50 and 55 years old, and the authors use the discontinuity in DI award rates at these points to estimate the effect of benefit receipt on labour supply. Their findings suggest that the receipt of disability benefits reduces labour force participation by six to twelve percent.

Recently, two other papers have focused their analysis on the veteran's disability compensation program, an alternative disability system in the United States. In this line of research, Angrist et al. (2010) use the draft lottery to determine the effects of Vietnam military service on both health and employment, and their findings suggest that military service during the Vietnam conflict decreased employment and increased the number of disability beneficiaries, but only in the case of lower skilled white men. Another recent paper by Boyle and Lahey (2010) uses an expansion in the veteran's affairs health care system in 1996-1997 in order to show how this greater availability of health insurance affected the labour market behaviour of several groups of veterans. Overall, their findings suggest that employment decreased in their sample for 
men who gained access to the veteran's health insurance program. These two papers (together with Autor and Duggan, 2007 and Autor et al., 2011) represent important contributions to the previous literature for being the first ones to focus on a disability system for which the receipt of the benefits is not contingent on working status. However, their results are not easy to interpret and extrapolate to the overall population, as it is difficult to understand the degree to which the decrease in employment rates is due to the receipt of disability benefits, or to the long-term health effects of military service.

Apart from evidence for the United States, there are two highly relevant studies looking at the impact of DI on LMP from other countries: one from Canada and one from Austria. The study by Gruber (2000) makes use of an increase introduced in 1987 of 36\% in the level of disability benefits in all Canadian regions except Quebec. He finds an elasticity of labour force non-participation of 0.28-0.36 with respect to higher generosity on disability insurance benefits. Staubli (2011) studies the effects on employment and DI enrolment of a 1996 Austrian law that increased the age for preferential access to DI benefits from 55 to 57 . He finds a decrease of 6.0 to 7.4 percentage points in the share of disability recipients aged 55-56, and an increase in employment of 1.6 to 3.4 percentage points. At the same time, he finds that the policy had some spill over effects to other Social Security programs, as it increased the share of individuals receiving unemployment and sickness benefits.

At a more international level, in an attempt to summarize the results and to raise the attention of both governments and the general public opinion about the distortions introduced by the relatively generous DI systems, the OECD calculated the disincentive effects to work using the "disability benefits net replacement rates" for average earners ${ }^{7}$. Additionally, in a companion report also published by the OECD (2003), a "benefit generosity indicator" was constructed and proved to have a positive correlation with both beneficiary rates and disability benefit inflows. This policy-oriented literature has, for some time, accepted the fact that disability systems in Europe are not only used for persons with health incapacities, but also as an alternative way to receive income support once the individual is no longer eligible to unemployment benefits, as well as an alternative pathway into early retirement, particularly for older individuals. As a result, countries have focused on the introduction of reforms to help disabled individuals find

\footnotetext{
${ }^{7}$ Net replacement rates compare the income situation when moving from paid work to receiving disability benefits without working (OECD, 2007a). These were estimated to be 39\% in Australia, between $43-60 \%$ in the UK, 74\% in Luxembourg and 64\%-84\% in the case of partial disability holders in Spain (121\% in the case of total disability).
} 
jobs, and to suppress the disincentives to work embedded in disability systems. Consequently, most of the recent literature relative to the European disability systems consists of policy evaluations of these reforms ${ }^{8}$.

For the particular case of Spain, a number of papers have tried to identify the extent to which disability benefits have been used as an alternative exit from the labour market for disabled individuals: Blanco (2000) uses a competing risk model to identify the characteristics that affect older individuals when leaving employment to enter early retirement or disability benefits, while Jimenez et al. (2009) focus on the effects of the business cycle on older workers going into disability benefits, unemployment or inactivity. Malo (2007) and Vall-Castello (2011) investigate the factors that influence the low employment rates of disabled individuals, and the later paper also finds positive effects of an employment promotion policy introduced in 2004 to foster the integration of disabled women into the labour market (specifically an increase in the deductions to the Social Security contributions offered to employers that hire disabled women). However, none of the literature about the Spanish DI system has tried to estimate the disincentive effect on employment induced by the level of disability benefits awarded. This paper is the first attempt to fill in this gap. Its findings should be of high interest since the specificities of the Spanish DI system make it very well-suited to estimate the income, rather than the substitution, effect of benefit generosity on labour market participation. We now turn to a detailed description of the Spanish disability insurance system.

\section{The Disability Insurance System in Spain}

\subsection{Types of Disability Insurance Benefits}

In Spain, permanent contributive disability insurance is defined as "the economic benefits that aim at compensating the individual for losing a certain amount of wage or professional earnings when the person is affected by a reduction or a complete loss of his/her working ability in a way that is assumed to be permanent due to the effects of a pathologic or traumatic process derived

\footnotetext{
${ }^{8}$ Examples of these evaluations are Humer et al. (2007) and Lalive et al. (2011) for Austria, Duell et al. (2009) for Norway, Bell and Heitmueller (2009) and Corden and Sainsbury (2001) for the U.K., Van Ours (2006) and Burkhauser et al. (2008) for The Netherlands, and Hartmann (2006) for Luxembourg, among others. See Aarts and De Jong (1996) for a now somewhat outdated European overview.
} 
from an illness or an accident”" . In order categorize a person's situation after suffering from a disabling condition, the Spanish Social Security administration differentiates between three main degrees of disability ${ }^{10}$ that depend on the amount of working capacity that has been lost:

(i) Partial Disability (57 percent of claimants): Individuals suffering from the kind of impairment that disables the individual from performing all of the fundamental tasks of his/her usual job or professional activity; the individual is still capable of performing a different job or professional activity.

(ii) Total Disability (40 percent of claimants): Individuals suffering from the kind of impairment that disables the individual from the performance of any kind of job or professional activity.

(ii) Severe Disability (3 percent of claimants): Individuals who, as a result of anatomic or functional losses, needs the assistance of a third person to perform the most essential activities of daily living, such as eating, ambulation, dressing, etc.

Therefore, even if working is not explicitly prohibited under any of the three types of disability benefits, the previously stated definitions suggest that only partial disability beneficiaries should be able to combine the disability benefits with a job. In practice, however, a small proportion of individuals in the total disability system are also observed as working in our database $^{11}$. In fact, when the Social Security administration defines the compatibilities of the benefits with a job, it states that the receipt of a total disability pension will not impede the development of those other activities (both paid and unpaid) that are compatible with the disability status of the individual, and that do not represent a change in her working ability.

These definitions were designed in the late 1970s when employment careers and the professional activity of the workers was clearly defined and stable through time, making it easy to identify the "usual job". However, the situation has changed very much in Spain in the last 30 years, and the current employment context, which is characterized by a higher share of temporary and unstable jobs, and by a higher mobility of workers between different types of jobs, makes it more difficult to assess the meaning of the "usual" job. Furthermore, the evaluation of whether the individual is able to develop his/her usual job is done at a very decentralized level by a group of experts in the provincial offices of the National Institute of

\footnotetext{
${ }^{9}$ Own translation of the definition of permanent disability given by the Spanish Social Security administration at www.seg-social.es.

${ }^{10}$ These three levels of disability represented $99.6 \%$ of DI claimants in 2007. A remaining $0.4 \%$ of claimants received a lump sum payment for every minor disability.

${ }^{11}$ An average of $1.4 \%$ of individuals in total disability are observed as working during the sample period.
} 
Social Security, which allows a certain flexibility for a differential interpretation of these definitions across Spanish regions.

Apart from the decision on the type of disability pension granted, the level of the benefits and the date of the next planned revision (to check for improvements or aggravations of the condition) are also decided at the regional level (in each of the 52 provinces of Spain). The date for future revisions of the disabling condition is set on an individual basis, depending on the chances of recovery/aggravation of each individual. In principle, these re-assessments do not depend on an individual's employment status, but only on the state and evolution of the disabling condition. As the data shows, revisions of a recipient's disability status are very rare in the Spanish system; once the benefits are granted, they are usually retained until automatically converted to old-age benefits at age 65 , or until the death of the claimant ${ }^{12}$. Unlike the U.S., there is no maximum amount of earnings above which disabled individuals will lose their disability benefits (i.e., no SGA) in the Spanish system. Claimants are allowed to work as much as they want while receiving disability benefits, as long as their "disabling” condition is not improving. As we are dealing with contributory DI, there are a number of rules in terms of eligibility requirements that the individual has to fulfil in order to qualify for the benefit. These requirements, as well as the regulatory base to calculate the amount of benefit, vary depending on the source of the disability (ordinary illness, work-unrelated accident or work-related accident). These are summarized in Table A1 of the Appendix.

The total amount of benefit received is then obtained from multiplying this regulatory base by a percentage which varies depending on the type of $\mathrm{DI}^{13}$. The percentage applied to the regulatory base is 55 or 75 percent under the Partial Disability regime, 100 percent under the Total Disability scheme, and 100 percent plus an extra 50 percent to cover expenses for the person who is taking care of the disabled individual in the case of Severe Disability. The types of DI available and benefit amounts that can be received in Spain are summarized in Table 1. In this paper, our main interest lies in the evaluation of the disincentive effects to work caused by the increase in the generosity of Partial Disability benefits from a replacement rate of 55 to 75 per cent available for older claimants. For this reason, our main analysis will focus on older

\footnotetext{
${ }^{12}$ Only 156 (1.1\%) individuals stopped receiving partial disability benefits and only 847 (5.5\%) were allowed to switch from partial to total disability benefits in our eleven-year sample. Excluding these individuals from our analysis does not affect our results.

${ }^{13}$ There is a maximum and minimum amount for partial disability benefits that is set by law (Table A2). However the minimum is very low and the maximum is very high, so most of the observations in our sample lie inside the (min, max) brackets.
} 
recipients of Partial Disability benefits who represent the majority of disability claimants in Spain. We now turn to a description of the policy treatment in which we are interested: the Disability Insurance Increase (DII).

\section{[TABLE 1 - ABOUT HERE]}

\subsection{The Disability Insurance Increase (DII)}

For partial disability pensioners, the 55 percent of the regulatory base can be increased to 75 percent for individuals who are "older than 55 years old" and "whose lack of education/preparation and the social and labour market conditions of the region in which they live make it difficult for them to find a job”14. This increase in the replacement rate of benefits was introduced in order to economically compensate those disabled individuals who reach age 55 with low prospects of finding a job. Therefore, individuals in the Partial Disability scheme who comply with these requirements can receive a 20 percentage point or one third increase in benefits at age 55 until their pension is automatically converted to old-age benefits at age 65 .

The DII is granted at the regional level by the provincial office of the National Social Security Institute after the disabled has filled in a form to request it (although the funds for the program come from the national Social Security administration). Unfortunately, there is no data available on how many claimants apply for the benefit increase, or on the proportions who successfully obtain it. However, after several discussions with DI case workers on the adjudication process, it emerged that almost all applications were accepted without much regard for the eligibility criteria, other than the age limit for eligibility. In other words, if a partial disability claimant asked for the higher replacement rate, he/she is almost guaranteed to receive it if he/she is more than 55 years old. The receipt of the DII in the system studied is, therefore, not only not contingent on work/income status, but also does not appear to depend on the actual probability of finding employment ${ }^{15}$. Is this potential 'non-selection' by the DI administration a

\footnotetext{
${ }^{14}$ Author's own translation of the official definition of the criteria for eligibility for the partial disability benefit increase as reported on the website of the Spanish Social Security administration: www.seg-social.es

${ }^{15}$ We see, in the descriptive statistics presented later (in Table 2), that those who receive the DI increase were much less likely to be employed before the age threshold for eligibility. This indicates that these claimants apply more often for the benefit bump which may be expected considering the requirement for low LMP for selection which is advertised in official documents even if it is not actually a strong criteria used in practice by social security administration staff.
} 
problem for the validity of our analysis? We actually believe that this is another feature of the Spanish DI system which makes this study highly relevant, and that the methodology employed still insures that our findings are consistent.

First, one may consequently have expected that all partial disability claimants who become older than 55 would ask for the higher replacement rate, as they are almost sure to obtain it. However, this is not the case as only about two thirds of claimants obtain the more generous benefit in the data, and we do not face a sharp discontinuity in treatment. If we accept that there is no administrative selection in granting the DII, we must accept that there is, however, a selection in the decision of claimants to apply for the higher benefit. This decision is likely to be motivated by individual characteristics of claimants usually not observed by researchers (e.g., self-perception, effort, ability). It is easy to argue that these characteristics are also certainly correlated to the probability of finding employment, whether negatively or positively. This means that there remains an endogeneity problem in estimating the impact of DII on LMP. Our $\mathrm{RD}$ approach should account for this factor as long as these unobserved claimant characteristics are randomly distributed around the age cut-off. Second, there is the possibility that the administration still exercises some discretion when granting the DII after claimants apply for it, even if we were not able to uncover this process. This is a more classic issue in the evaluation literature when researchers do not have exact information on the selection mechanism into treatment. However, this should not be problematic in this setting, as we know that the age criteria is still stringently respected, and it is the main requirement for our RD identification strategy to be implemented (given it passes the validity tests on covariates that we subsequently demonstrate). This policy is therefore perfectly suited to estimate the impact of benefit increases on the potential disincentives to work when there is mainly an income effect at play.

\section{Data and Descriptive Statistics}

\subsection{The Data}

We make use in this paper of the Continuous Sample of Working Lives ("Muestra Continua de Vidas Laborales”, MCVL) which is based on administrative records provided by the Spanish Social Security Administration. It contains a random sample of 4 percent of all the individuals who, at some point during 2007, had contributed towards the social security system (either by working or being in an unemployment scheme) or had received a contributory DI benefit. The 
random sample selected covers over one million individuals. It contains information on the monthly employment and benefit history of the workers, including the exact duration of employment, unemployment and disability benefit spells, and for each spell, several variables that describe the characteristics of the job or the unemployment/disability benefit. The definition of being employed (i.e., LMP) is therefore simply to be engaged or not in a work contract in a certain month. We also have information on the type of disability benefit (partial, total or severe) and the percentage of the regulatory base that each individual is receiving. Therefore, we can identify exactly the individuals that receive the increase in the benefits at age 55 .

The MCVL also contains some information on personal characteristics such as age, gender and level of education. We capture the economic business cycle by compiling quarterly unemployment rates at the province level (there are 52 provinces in Spain). Our sample is composed of all individuals who are aged 51-58 and are observed as receiving Partial Disability benefits at some point between 1996 and 2007. The final sample for our analysis contains 623,228 monthly observations for 14,692 individuals who are receiving disability benefits in our sample period. One potential shortcoming of this data is that we do not observe applications to the DI system, and we only observe individuals once they are accepted into the system. We do not believe this to be a problem here (as explained previously), as our interest lies in the potential disincentive effects on LMP from the increase in the generosity benefits at age 55, and we have all the necessary information to estimate it.

\subsection{Descriptive Statistics}

Table 2 reports the main descriptive statistics of DI claimants in our sample. Due to the age criteria for eligibility for the benefit generosity bump, we always make a distinction between those younger and older than 55 . We then split the sample along different lines of disability insurance increase (DII) receipt status: First, whether in a certain monthly observation the claimant receives it (DII $=1$ ) or not (DII $=0)$, and second whether the individuals observed in our sample are ever or never treated. In terms of age, gender and education level, there are no striking differences between these groups. However, it appears that those receiving DII started receiving the benefits when they were on average almost two years older than those who did not. This is a first indication that there may be an entry effect into DI due to the policy that we will have to carefully investigate. The largest dissimilarities observed are in the labour market 
participation (LMP) of claimants which is always much lower for those receiving, in a certain month or ever, DII. This is not surprising considering that the probability of employment is a criterion for eligibility for the benefit generosity bump. Therefore, the fact that the drop in LMP is much larger for the ever compared to never treated is the first evidence that DII does have a disincentive to work effect for those who receive it. We will obtain precise statistical measures of this effect in our subsequent analysis, but we first consider the validity of adopting a regression discontinuity (RD) approach with graphical illustrations of the characteristics of claimants around the age 55 eligibility threshold.

\section{[TABLE 2 - ABOUT HERE]}

We observed some important differences in the age at which individuals started receiving disability benefits, depending on whether they receive the benefit increase or not. Figure 1 plots the distribution of the proportion of entries into DI and, as we suspected, it clearly points to a large jump in the number of new claimants between ages 54 and 55 . This could be problematic for our analysis as it suggests that a substantial number of new claimants are attracted by the higher available benefit once they become old enough to be eligible. The impact on LMP of the policy estimate would then not only stem from an income effect on existing claimants receiving more generous DI, but also from an entry effect of individuals who were not claiming at the lower replacement rate. More worrying is the potential validity issues it raises for our RD approach, as the 'age started claiming' covariate is not continuous around the eligibility age threshold $^{16}$. To address these two problems, we propose the simple solution of considering not only the whole sample, but also a restricted sample of claimants who entered the DI count before the age threshold. We then apply this throughout the rest of our analysis. This should address the

\footnotetext{
${ }^{16}$ The main issue raised is linked to RD identification being dependent on the inability of individuals "to precisely manipulate the assignment variable” (Lee and Lemieux, 2010, p. 283). This is practically tested by showing that "all "baseline characteristics" - all those variables determined prior to the realization of the assignment variable - ... have the same distribution just above and below the cutoff" (Ibid.). Age started claiming is not exactly a "baseline characteristic" since it is, by construction, different for those who enter DI at older ages - the assignment variable. One must also remember here that the eligibility for treatment is age of claimants and not age started claiming. Figure 1 is therefore not evidence of manipulation of the running variable, which would be difficult in any case, as age is not such a good candidate for this, which McCrary (2008) suggests could be problematic in a RD setup. The distribution of age in months is itself very smooth around the threshold. This specific 'entry effect' problem is not often discussed in the RD methodology, but we believe it can be addressed with the simple sample restrictions we propose here.
} 
issue of isolating the effect of the benefit bump on LMP, and fulfil the conditions for the RD design to be valid.

\section{[FIGURE 1 - ABOUT HERE]}

Our methodological approach, described in detail in section 5, first relies on an actual discontinuity in the receipt of the 36 percent DII when claimants are younger or older than 55 . We present the proportion of treated individuals by age in Figure 2 for the whole sample (top graph) and the restricted sample (lower graph), and we also make this distinction in all subsequent figures. This reveals a jump of about 60 percent in the proportion receiving DII, and does warrant evaluation using a fuzzy regression discontinuity design. We then check that the treatment discontinuity is not a result of differences in covariates around the age threshold graphically. Figure 3 shows that women constantly represent approximately one third of our sample of claimants. In Figure 4 we see that older individuals are on average less educated than younger cohorts, but the graph is reassuring and shows that this criterion for eligibility to the benefit increase appears to be very smooth around the age cut-off. The pattern for age started claiming DI in Figure 5 is reversed, with older benefit recipients having on average entered the benefit roll older. The distribution of average age when individuals started claiming is slightly discontinuous around age 55 for the whole sample in the upper graph. As previously discussed, this stems from an entry effect of DII, which is no longer problematic when we look at the restricted sample graph which is now very smooth around the age threshold.

\section{[FIGURE 2 - ABOUT HERE] \\ [FIGURE 3 - ABOUT HERE] \\ [FIGURE 4 - ABOUT HERE] \\ [FIGURE 5 - ABOUT HERE]}

Finally we plot the changes in our outcome of interest, LMP, by age in Figure 6. Again we see that the detachment from the labour market increases from age 52 onwards as our sampled individuals become older ${ }^{17}$. We also note what appears to be a noticeable downward drop in both

\footnotetext{
${ }^{17}$ The marked drop in LMP at age 52 onward is still relatively puzzling to us since there are no disability insurance entitlement changes at this age. It could be due to the 'natural' effect of age on LMP as claimants become older, and we therefore carefully control for this phenomenon in our statistical analysis by including "age" in the model.
} 
graphs after the age cut-off which we tentatively attribute to the change in treatment probability. The significance of this gap is however difficult to judge graphically, and will be tested in our statistical model estimates.

[FIGURE 6 - ABOUT HERE]

\section{$5 \quad$ Methodology}

\subsection{OLS, DiD, and FE Models}

For individual $i$ in month $t$, a simple statistical model relating LMP (our outcome of interest) to DII receipt (the policy treatment) can be written as:

$$
L M P_{i t}=\alpha+\beta D I I_{i t}+\delta(A g e)+\gamma_{k} X_{k i}+\eta U R_{i t}+Y r_{t}+u_{i t}
$$

where $\alpha$ is an intercept, $L M P$ is a dummy variable for working or $\operatorname{not}^{18}, D I I$ a dummy variable for receiving the disability benefit increase and $u$ is an error term. It includes a cubic (thirdorder) polynomial of age in months, $\delta(A g e)$, because of the observed negative correlation between LMP and age, and to account for the potential non-linearity of this relationship. We also include $k$ individual characteristics (gender, education and age started claiming DI) in the vector of control variables, $X$. Finally, $U R$ is the unemployment rate the claimant is exposed to in the area where he resides in month $t$, and $Y r$ is a set of year dummies. The Ordinary Least Squares (OLS) estimate of $\beta$ is then the relationship between $L M P$ and $D I I$ net of age effects, holding constant the X's, and controlling for labour market and other macro-economic conditions.

However, the definition of having a low LMP probability for DII selection is likely to be dependent upon unobserved individual characteristics, and the impact estimated by (1.1) will be biased - overestimating the decreases in employment rates due to the programme. We can consider two possible ways of partially dealing with this problem. First, we can include indicator variables for DI claimants ever receiving the benefit increase and for them being older than 55

\footnotetext{
${ }^{18}$ Our analysis will therefore concentrate on the extensive margin of the employment effect of the policy. The data contains information on the proportion of a full-time position for an employed claimant's work contract (0.1 to 1$)$. In Spain part-time employment is not very common, and more than $90 \%$ of contracts in our data are full-time positions. We still tried to use this information to obtain some measure of the intensive marginal effect of the policy, but as could be expected, the results were almost exactly similar to using a dummy for LMP. Looking at earnings would be another option to study the effect of the policy on the employment intensive margin but these are unfortunately too poorly recorded in the data to be credibly used as the outcome variable.
} 
(when the increase becomes available). This is akin to a Difference-in-Differences (DiD) approach to estimate the treatment effect, as this treatment (DII) kicks in at different $t_{s}$ for different $i_{s}$. Second, we can exploit the panel nature of our data and include individual fixed effects (FE), $\alpha_{\mathrm{i}}$, as follows:

$$
L M P_{i t}=\alpha_{i}+\beta D I I_{i t}+\delta(\text { Age })+\eta U R_{i t}+Y r_{t}+u_{i t}
$$

The individual characteristics, $X s$, from (1.1) are now dropped since they do not vary over time. Our interpretation of the $\mathrm{DiD}$ and $\mathrm{FE}$ estimated $\beta s$ is that they should now be free of observed and unobserved claimant characteristics. Still, if selection into DII is dependent on other factors not included in the model that have an effect on $L M P$, and are hidden in $u$, the selection problem remains and these will not be unbiased estimates of $\beta$. Since the rule for DII selection is that claimants must be over 55 years old, we consider another methodology which should be better at addressing the discussed selection problem: Regression Discontinuity.

\subsection{Regression Discontinuity Models}

Regression Discontinuity (RD) design has had a long history in statistics, but has recently gained prominence among economists for its potential for dealing with the problem of unobservable characteristics as well as its conceptual simplicity ${ }^{19}$. This method can only be applied when there exists a cut-off point of an assignment variable $Z$, above and below which there is a strong difference in treatment probability. As we clearly illustrated in Figure 1, this is the case for DII treatment depending on age of the claimant $(Z)$ due to the 55 years minimum selection rule.

A widely researched and very intuitive example of RD occurs for the 50 percent cut-off rule for winning or losing an election. The argument is that different units (areas, firms) which have had very close votes around the cut-off are likely to be very similar in observed and unobserved characteristics. Still, they will have opposite outcomes whether they were above or below the assignment cut-off, making it very simple to compare the different impact of selection or not. In this instance, an unbiased treatment effect on an outcome, here $L M P$, with subscripts + and - indicating proximity to either side of the threshold can be written as:

$$
\beta=L M P^{+}-L M P^{-}
$$

\footnotetext{
${ }^{19}$ For a clear and detailed discussion on the RD methodology, see for example Imbens and Lemieux (2008) or Lee and Lemieux (2010).
} 
It is extremely simple to estimate $\beta$ here since being above the cut-off guarantees treatment, and we only have to compare the means of the outcomes around that point. This is called a sharp RD, as the probability of treatment, or inclusion into a program, jumps from 0 to 1 on either side of the cut-off.

For DII treatment, as in many other programs, the change in the probability of treatment around the assignment variable threshold is not sharp but does greatly increase. This type of set up is called a fuzzy RD, and it is still possible to exploit the discontinuity to identify a treatment effect ${ }^{20}$. The difference in outcomes around the cut-off will be a function of the difference in the jump in the proportion treated around this point. Mathematically, using average LMP, the mean proportion of claimants receiving DII, and the subscript + and - as after and before, we can write $L M P^{+}-L M P^{-}=\beta\left(D I I^{+}-D I I^{-}\right)$. This can be re-written as the RD estimator:

$$
\beta=\frac{L M P^{+}-L M P^{-}}{D I I^{+}-D I I^{-}}
$$

If it is the case that claimants just below and just above the age cut-off do have similar characteristics (observable and unobservable), then the estimator in equation (2.1) can legitimately be used to estimate the causal impact of DII on LMP. This is because it simply compares the difference in employment rates of individuals which have been randomly assigned around an assignment threshold, and which should consequently have similar characteristics. Of course, since not all claimants over 55 receive the benefit increase, this must be scaled by the difference in the jump in the proportion of individuals that are treated around this point.

We can estimate $\beta$ using different + and - windows in terms of age on each side of the threshold. As the age difference of individuals around the threshold becomes smaller, we expect the RD estimate of the DII treatment to decrease, since claimants on either side will be ever more similar in observed (and unobserved) characteristics. This implies that the ignorability assumption is met and that treatment is randomly assigned on observables. A more robust test of this assumption is to check for smoothness around the threshold. Therefore, in the previouslydescribed graphical illustration, this is to include individual characteristics of our claimants as controls when obtaining the RD estimates of DII on LMP in the smallest age window selected. If

\footnotetext{
${ }^{20}$ In our case, we are actually facing what has been referred to as a 'simple special case' by Blundell and Costa Dias (2009) version of the RD methodology. This is because treatment is only available but not mandatory on one side of the threshold. These authors highlight the econometric advantages of this approach relative to the standard fuzzy RDD.
} 
these characteristics are smoothly distributed around the age cut-off, we expect that including controls will not significantly change the RD estimates. But if they become significantly different from zero with the inclusion of certain individual trait of DI claimants, it will suggest that we must consider how this affects the validity of our RD results.

Another issue for identification in an RD design is the possibility for individuals to precisely 'sort' themselves around the assignment variable threshold to obtain treatment. As in this paper the main eligibility criterion is age and administrative data is used to measure it, we can easily argue that the sorting explanation holds no weight here. However, we showed that some level of manipulation seems to occur in terms of individual choices to start claiming DI before and after the age cut-off. This could affect the validity of the RD estimate, and it would be revealed by obtaining a statistically different $\beta$ after including 'age started claiming' as a covariate in our models. To rule out all potential effects of partial sorting from this phenomenon, we will turn to our restricted sample which limits entry into DI to individuals who enter at an age below the eligibility threshold for the treatment. Then the RD estimates of $\beta$ obtained should be an unbiased measure of the (income) effect of disability insurance generosity on labour market participation.

Finally, when interpreting our findings, we must remember that, while this methodology is able to account for the endogeneity of treatment and outcome, it will yield an estimate of the local average treatment effect (LATE). This is because the impact of the policy will be measured for claimants near the 55 age cut-off with somewhat low employability, and it could have a different behavioural effect on older or younger individuals. However, to argue in favour of the relative generisability of the estimate, we can consider the slope of LMP in Figure 6. This slope appears extremely consistent from age 52 onwards, apart from the drop at the eligibility age threshold. We can therefore assume that a similar fall in LMP would be observed if the benefit increase was applied at another age cut-off along the slope. In other words, we can argue that our findings should be at least generalisable to the employment response by older claimants with an increase in the generosity of DI in Spain. Since this group represents the largest and fastest growing proportion of claimants, and the study is done in a context where benefit receipt is not work contingent, we believe our results to be highly relevant in policy terms.

\section{Results and Robustness Checks}




\subsection{OLS, DiD, and FE Results}

Table 3 reports the results from the OLS, DiD, and the FE models of the impact of DII on LMP with all the controls included. The OLS estimates are negative and extremely large, with 16 and 19 percent drop in employment, when using respectively the whole sample in column (1) and the restricted sample in column (2). We may have expected these results since these estimates are certainly strongly biased, because the selection process for treatment is contingent on having a low employment probability, which is our outcome variable. The DiD and FE estimates are much smaller and very similar. They suggest a reduction in employment of 5 percentage points when using the whole sample in columns (3) and (5). We see however that with the restricted sample, the DiD estimate in column (4) becomes larger, while the FE estimate in column (6) are unchanged. This is simply because the FE model is not affected by the potential entry effect of the policy on LMP: it is not influenced by the inclusion of individuals who only start claiming after age 55 because of the higher replacement rate and who never work. The DiD (and OLS) estimates are affected by the sample composition. We therefore believe the FE models to yield a more accurate estimate of the DII impact, since it measures the average effect of switching from non-treatment to treatment in terms of changes in LMP for the same individual. However, as explained previously, we may still be concerned that individual fixed effects and labour market conditions cannot account for the endogenous nature of selection for treatment and the behavioural response of claimants. For this we turn to the RD analysis.

\section{[TABLE 3 - ABOUT HERE]}

\subsection{RD Results}

Table 4 reports RD estimates for four different age windows (from +/- 4 years to +/- 1 year) around the 55 year threshold for the whole sample. The discontinuity in DII is clearly important, and represents a jump of between 50 and 60 in the proportion of treated claimants. The difference in LMP is significant, and ranges between 5.1 and 1.6 percentage points lower after the age cut-off. The RD coefficients are the ratios of these differences, and they are all 
statistically significant ${ }^{21}$. However, it is clear that the impact of DII on LMP becomes much smaller when the age window around the threshold is reduced, as the individuals in our sample become ever more similar. Our first raw RD results therefore suggest that an increase in DI generosity reduces the probability of working by at least 3 percentage points.

\section{[TABLE 4 - ABOUT HERE]}

Table 5 reports RD estimates which include DI claimant individual characteristics for the 55 year old $+/-1$ year age window ${ }^{22}$ for the whole sample. The second and third columns show that the inclusion of gender and secondary education completion dummies do not significantly change the estimated impact of the DI increase on LMP which remains roughly at -0.03 . However, the inclusion of the age at which individuals started claiming disability benefits generates an RD estimate three times smaller (and it is not affected by the inclusion of year dummies). This finding confirms our suspicions that this covariate is not smoothly distributed around the eligibility age threshold as we noted from the top graph of Figure 5. Making use of the sample restricted to claimants who enter DI before the age cut-off should enable us to account for this partial sorting, through entry decision, of individuals around the assignment variable.

\section{[TABLE 5 - ABOUT HERE]}

We report RD estimates for the +/- 1 year window for the restricted sample in Table 6 . We first note that our RD estimates are now statistically unchanged by the inclusion of all covariates, including age started claiming DI. This confirms the smooth distribution of individual characteristics around the age cut-off shown in the lower graphs of Figures 3 to 5 . We therefore argue that this is an unbiased measure of the policy effect, and conclude that the net impact of

\footnotetext{
${ }^{21}$ As the estimate is similar to a local IV estimate of DII on LMP instrumented by a claimant being older than the cut-off age, we are able to obtain standard errors using the methodology recommended by Hahn et al. (2001). Since some individuals are observed both before and after the threshold, we must account for within-individual correlation of the errors over time using clustered standard errors as highlighted by Lee and Lemieux (2010).

${ }^{22}$ Our focus on this $+/-1$ year window is justified econometrically as the calculation of the optimal bandwidth, following the methodology proposed by Imbens and Kalyanaraman (2009), yielded a value of 0.94 (years) on each side of the threshold for eligibility age.
} 
DII is to reduce LMP by 1 percentage point, which translates into a drop in employment of roughly 8 percent in our sample ${ }^{23}$.

\section{[TABLE 6 - ABOUT HERE]}

\subsection{Robustness Checks}

In order to further check the robustness of our findings, we consider the effect of a placebo policy on two claimant groups who do not receive treatment. First we focus on the same category of partial DI beneficiaries, but set a placebo policy that begins at age 54 instead of 55 . Second we consider the LMP impact for a category of claimants who do not experience any change in the generosity of their benefits at age 55: total disability claimants. We frame both placebo experiments in the RD framework with a +/- 1 year window which includes all controls. As there are no actual jumps in the proportion treated now, we can obtain estimates of the change in employment, $L M P^{+}-L M P^{-}$, which is in practice equivalent to an IV reduced form. If this is significant for any of our two placebo experiments, this would cast doubts on the robustness of our previous findings. It would, in fact, suggest that the measured drop in LMP for partial disability claimants around the 55 age threshold is not driven by DII but by another factor. Alternatively, it could also mean that the relationship is simply spurious. The results from this exercise are reported in Table 7 for the partial disability claimants around age 54 in column (1), and for total disability claimants around age 55 in column (2). The coefficients on both placebos are not significantly different from zero ${ }^{24}$, and we are therefore reassured that the previously measured policy effect for partial disability claimants around age 55 is not spurious.

\section{[TABLE 7 - ABOUT HERE]}

\footnotetext{
${ }^{23}$ The average LMP for this sample is of $12.5 \%$ and thus a 1 percentage point decrease corresponds to an 8 percent drop in employment probability.

${ }^{24}$ The impact on employment for partial disability claimants age 54 is slightly negative but not significant. We may argue that this is because it captures some level anticipation effect for claimants age 54 to 55 who already reduce their LMP knowing that they will get the benefit payment bump the following year.
} 


\section{Conclusions}

In this paper we analyse the employment effects of a 36 percent increase in the amount of disability pensions (DII) that is granted to almost 60 percent of the individuals aged 55 or above who are receiving a partial disability pension in Spain. The DI system in Spain allows partially disabled claimants to combine the receipt of benefits with income from employment without any implicit tax on labour supply being levied.

We exploit this discontinuity of DII provision from age 55 onwards and first apply a straightforward fuzzy regression discontinuity approach to estimate the effect of treatment on LMP (which are likely to be endogenously determined). We generate RD estimates using different age windows, from $+/-4$ to 1 year before and after the cut-off age, which suggests that the increase in DI generosity reduces the probability of working by at least 3 percentage points.

However, once we model more carefully for the impact of other individual characteristics, we discover an acceleration of entry into DI for claimants age 55 and older, which we believe is partly due to the increased generosity of available benefits. Once we take this phenomenon into account, we estimate that the employment of DI recipients would have been 8 percent higher if they had not received the benefit generosity increase. Since the replacement rate is in practice increased by 36 percent, this translates into an elasticity of DI generosity to LMP of approximately 0.22 .

These results are very much in line with the literature on the employment effect of DI which almost unanimously concludes a negative causal relationship. Our results, nevertheless, are an important contribution for two distinct reasons. First, they are among the original, with Gruber (2000), to focus on the impact of benefit generosity rather than entitlement. Second, the features of the DI institutional system we study make it possible to rule out the idea that this impact stems from a substitution effect. As benefit receipt is not work contingent, it suggests that there is an important income effect at play in the work decision of older workers as argued by Autor and Duggan (2007, 2008).

This latter point is important as it has potential implications in terms of the efficiency of DI policy, since an income effect does not imply any deadweight loss. We believe this should be seriously considered in future reforms which may use the disincentive substitution argument to cut the level of benefits of a group in an already relatively weak income position. This is 
especially true considering the findings of Bound et al. (2004) which stress that workers, on average, value increased benefits somewhat above the average cost of providing them. 
Acknowledgments: We thank the editor, Mark Duggan, and two anonymous referees for their very valuable suggestions on previous versions of this paper which have greatly improved it. We are grateful for comments received at seminars at Baruch College, Cornell University, Stony Brook University, Maastricht University, Universitat de Girona and at the ESPE 2010 (Essen), and EEA 2010 (Glasgow) conferences. Marie would like to thank the Executive Research Agency of the European Union for funding under the Marie Curie IEF grant number 252572. Vall Castello would like to thank the Cournot Centre for Economic Research for granting her a Robert Solow Postdoctoral Fellowship. 


\section{References}

Aarts, L.J.M., De Jong, P.R., 1996. European Experiences with Disability Policy, in: Mashaw, J.L., Reno, V., Burkhauser, R.V., Berkowitz, M. (Eds.), Disability, Work and Cash Benefits. W.E. Upjohn Institute for Employment Research: Kalamazoo, Michigan.

Angrist, J., Chen, S.H., Frandsen, B.R., 2010. Did Vietnam Veterans Get Sicker in the 1990s? The Complicated Effects of Military Service on Self-Reported Health. Journal of Public Economics. 94, 824-837.

Autor, D.H., Duggan, M.G., 2006. The Growth in the Social Security Disability Role: A Fiscal Crisis Unfolding. Journal of Economic Perspectives. 20, 71-96.

Autor, D.H., Duggan M.G., 2007. Distinguishing Income from Substitution Effect in Disability Insurance. American Economic Review Papers and Proceedings. 97, 119-124.

Autor, D.H., Duggan M.G., 2008. The Effect of Transfer Income on Labor Force Participiation and Enrollment in Federal Benefits Programs: Evidence from the Veterans Disability Compensation Program. A Report to the Social Security Administration. Unpublished.

Autor, D.H., Duggan M.G., Lyle D.S., 2011. Battle Scars? The Puzzling Decline in Employment and Rise in Disability Receipt Among Vietnam Era Veterans. American Economic Review Papers and Proceedings. 101, 339-44.

Blanco, A., 2000. The Decision of Early Retirement in Spain. FEDEA. EEE 76.

Bell, D., Heitmueller, A., 2009. The Disability Discrimination Act in the UK: Helping or Hindering Employment Amongst the Disabled?. Journal of Health Economics, 28, 465-480.

Blundell, R., Costa Dias, M., 2009. Alternative Approaches to Evaluation in Empirical Microeconomics. Journal of Human Resources. 44, 565-640.

Bound, J., 1989. The Health and Earnings of Rejected Disability Insurance Applicants. American Economic Review. 79, 482-503.

Bound, J., Cullen, J.B., Nichols, A., Schmidt, L., 2004. The Welfare Implications of Increasing Disability Insurance Benefit Generosity. Journal of Public Economics. 88, 2487-2514.

Boyle, M.A., Lahey, J.N., 2010. Health Insurance and the Labor Supply Decisions of Older Workers: Evidence from a U.S. Department of Veterans Affairs Expansion. Journal of Public Economics. 94, 467-478.

Burkhauser, R.V., Daly, M.C., De Jong, P.R., 2008. Curing the Dutch Disease: Lessons for United States Disability Policy. Michigan Retirement Research Center Working Paper 2008-188.

Chen, S., Van der Klaauw, W., 2008. The Work Disincentive Effects of the Disability Insurance Program in the 1990s. Journal of Econometrics. 142, 757-784. 
Corden, A., Sainsbury, R., 2001. Incapacity Benefits and Work Incentives. Research Report.141, Department for Work and Pensions, London.

Duell, N., Singh, S., Tergeist, P., 2009. Activation Policies in Norway. OECD Social Employment and Migration Working Papers. 78, OECD Publishing.

Gruber, J., 2000. Disability Insurance Benefits and Labor Supply. Journal of Political Economy. $108,1162-1183$.

Hahn, J., Todd, P., Van Der Klaauw, W., 2001. Identification and Estimation of Treatment Effects with a Regression-Discontinuity Design. Econometrica. 69, 201-209.

Hartmann-Hirsch, C., 2006. L'incapacité de travail. Une mesure de maintien à l'emploi aux effets pervers?. Population et Emploi. 19, CEPS/INSTEAD, Luxembourg.

Humer, B., Wuellrich, J.P., Zweimüller, J., 2007. Integrating Severely Disabled Individuals into the Labour Market: The Austrian Case. IZA Working Paper 2649. Institute for the Study of Labor (IZA).

Imbens, G., Kalyanaraman, K., 2009. Optimal Bandwidth Choice for the Regression Discontinuity Estimator. NBER Working Paper 14726.

Imbens, G., Lemieux, T., 2008. Regression Discontinuity Designs: A Guide to Practice. Journal of Econometrics. 142, 615-635.

Jiménez-Martín, S., Vall-Castello, J., 2009. Business Cycle Effects on Labour Force Transitions for Older People in Spain. FEDEA Working Paper 2009-25.

Lalive, R., Wuellrich, J.P., Zweimüller, J., 2011. Do Financial Incentives for Firms Promote Employment of Disabled Workers? A Regression Discontinuity Approach. Forthcoming in the Journal of the European Economic Association.

Lee, D.S., Lemieux, T., 2010. Regression Discontinuity Designs in Economics. Journal of Economic Literature. 48, 281-355.

Livermore, G., Stapleton, D. Roche, A., 2009. Work Activity and Use of Employment Supports under the Original Ticket to Work Regulations: Characteristics, Employment and Sources of Support among Working-Age SSI and DI Beneficiaries. Mathematica Policy Research, Inc. Report submitted to the Social Security Administration.

MacCrary, J., 2008. Manipulation of the Running Variable in the Regression Discontinuity Design: A Density Test. Journal of Econometrics. 142, 698-714.

Maestas, N., Yin, N., 2008. Labor Supply Effects of the Interaction between the Social Security Disability and Retirement Programs at Full Retirement Age. Michigan Retirement Research Center Research Paper 2008-194. 
Malo, M.A., Cueto, B., Rodríguez, V., 2007. Compatibilidad entre Pensiones Contributivas por Incapacidad y Empleo: El Caso Español. Unpublished.

OECD, 2003. Transforming Disability into Ability: Policies to Promote Work and Income Security for Disabled People. OECD, Paris.

OECD, 2007a. Sickness, Disability and Work: Breaking the Barriers - Vol. 2: Australia, Luxembourg, Spain and the United Kingdom. OECD, Paris.

OECD, 2007b. Benefits and Wages. OECD, Paris.

OECD, 2008. Sickness, Disability and Work: Breaking the Barriers: Vol. 3: Denmark, Finland, Ireland and The Netherlands. OECD, Paris.

OECD, 2009. Sickness, Disability and Work: Keeping on Track in the Economic Downturn: Background Paper. OECD, Paris.

Staubli, S., 2011. The Impact of Stricter Criteria for Disability Insurance on Labor Force Participation. Journal of Public Economics, 95, 1223-1235.

Van Ours, J.C., 2006. Leaving “Hotel California” How Incentives Affect Flows of Benefit Recipients in The Netherlands. CentER Discussion Paper 2006-116.

Vall-Castello, J., 2011. Promoting Employment of Disabled Women in Spain: Evaluating a Policy. Forthcoming in Labour Economics.

Von Wachter, T., Song, J., Machester, J., 2011. Trends in Employment and Earnings of Allowed and Rejected Applicants to the Social Security Disability Insurance Program. Forthcoming in the American Economic Review. 
Figure 1: Distribution of Age at Entry into DI

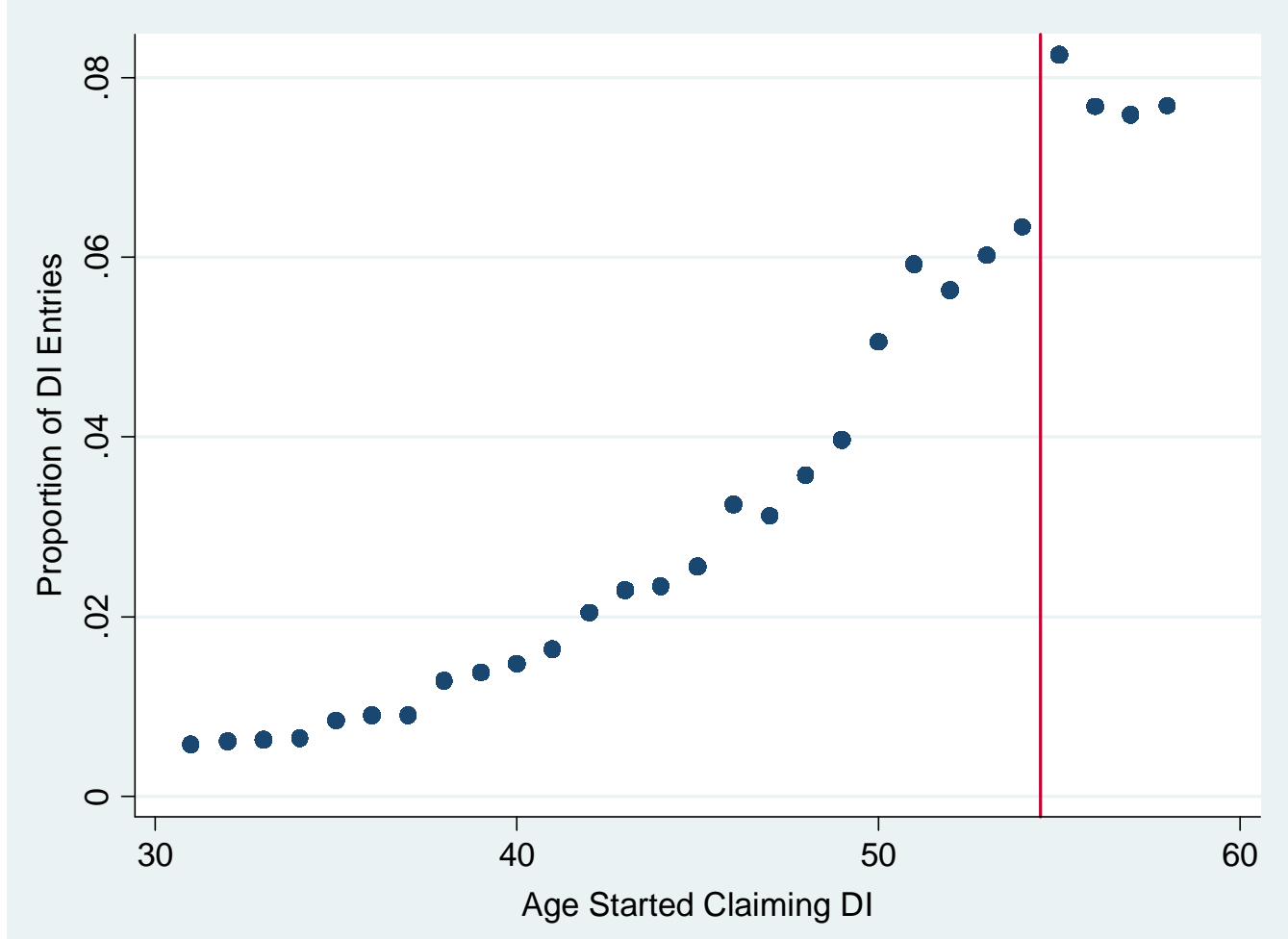

Note: Each dot represents the proportion of entries into DI by age. The vertical red line marks the limit at age 55 for eligibility to the DI increase. 
Figure 2: Proportion of Claimants Receiving the DI Increase by Age
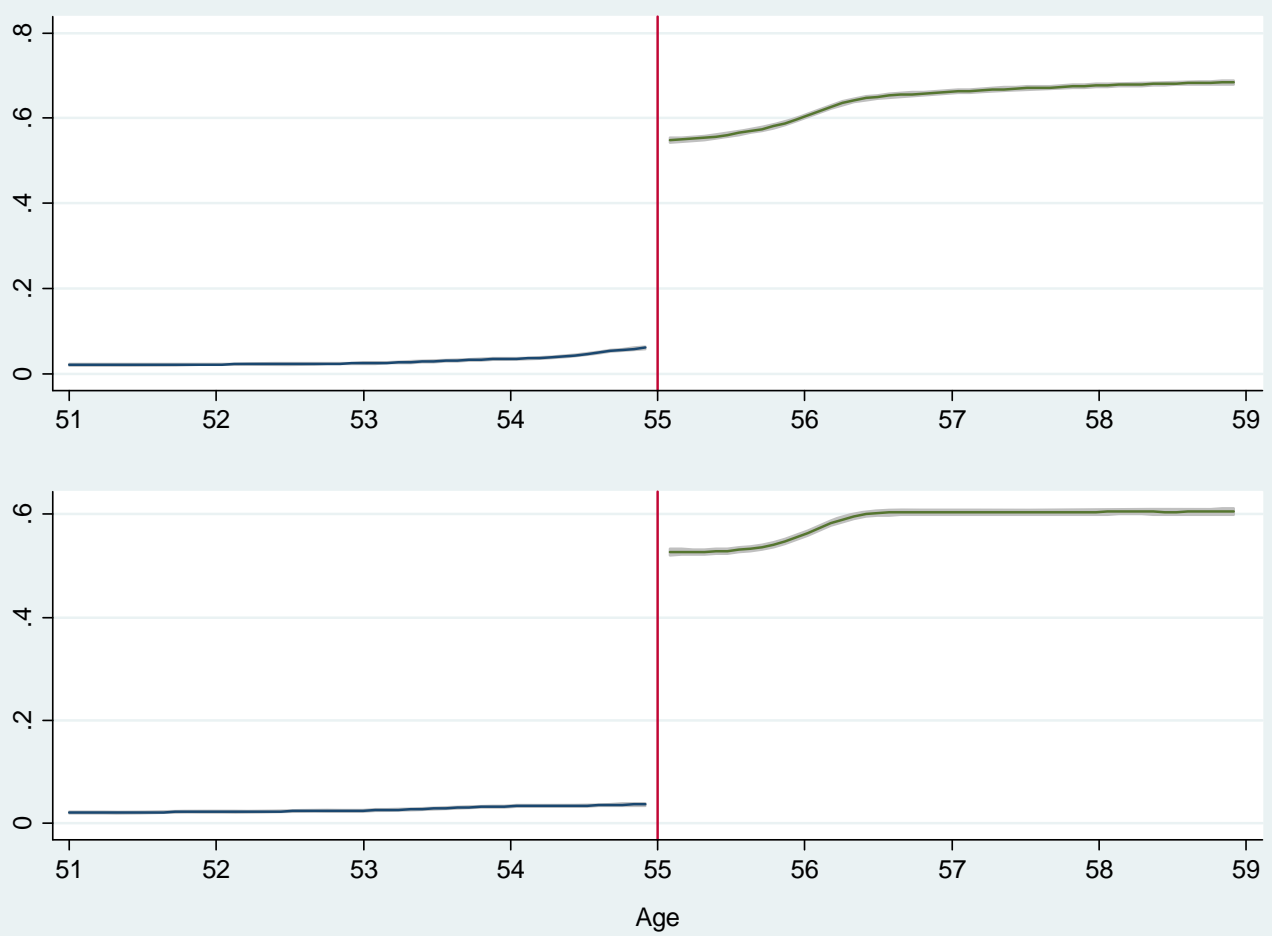

Notes: The top graph is for the unrestricted sample and the bottom one when restricting to individuals who started claiming before age 55 . The vertical red lines marks the limit at age 55 for eligibility to the DI increase. Local polynomials are smoothed by two months periods. Grey areas show the 95 percent confidence intervals around these polynomials. 
Figure 3: Proportion of DI Claimants who are Women by Age
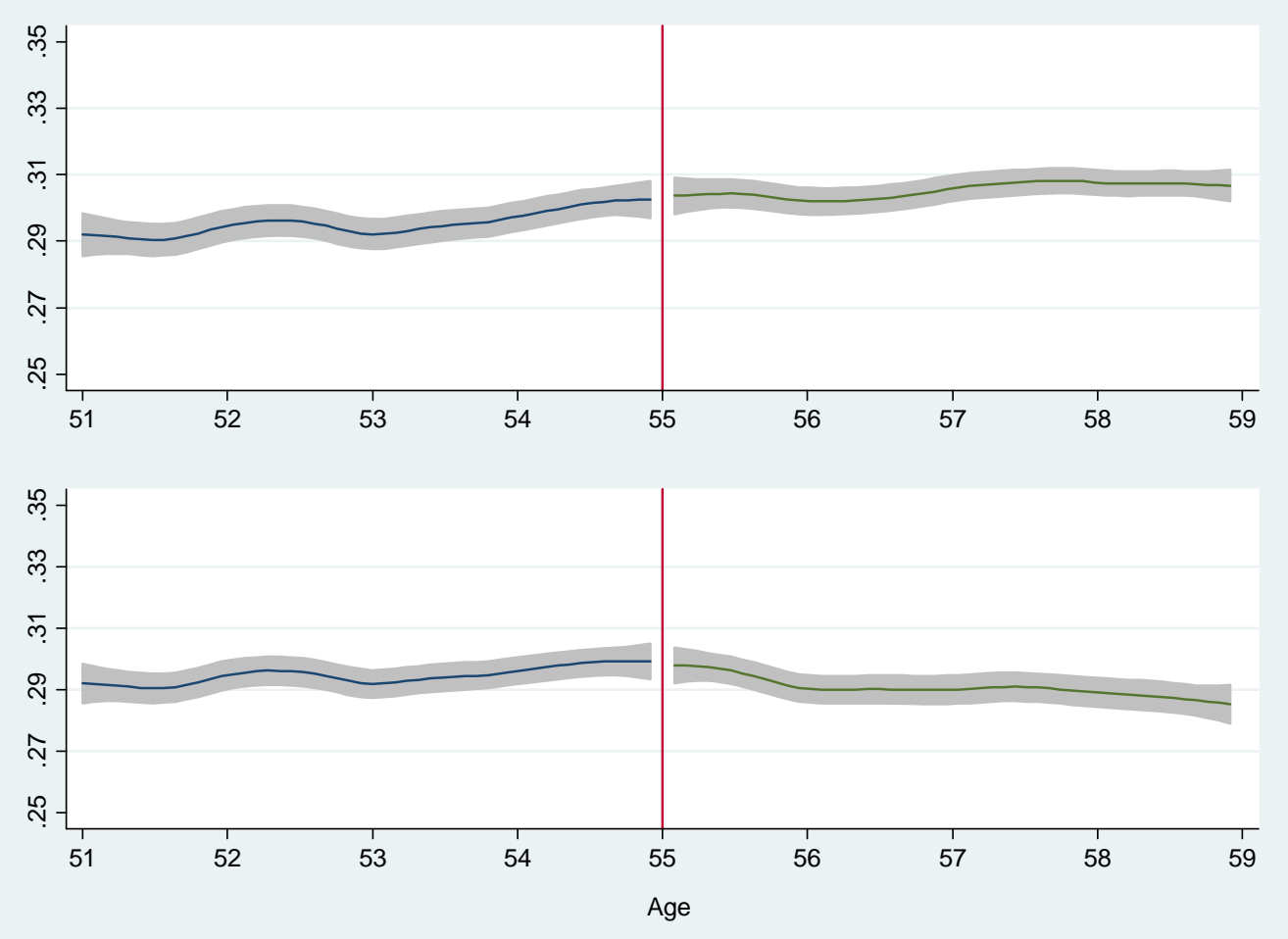

Notes: The top graph is for the unrestricted sample and the bottom one when restricting to individuals who started claiming before age 55 . The vertical red lines marks the limit at age 55 for eligibility to the DI increase. Local polynomials are smoothed by two months periods. Grey areas show the 95 percent confidence intervals around these polynomials. 


\section{Figure 4: Proportion of DI Claimants with Secondary Education by Age}
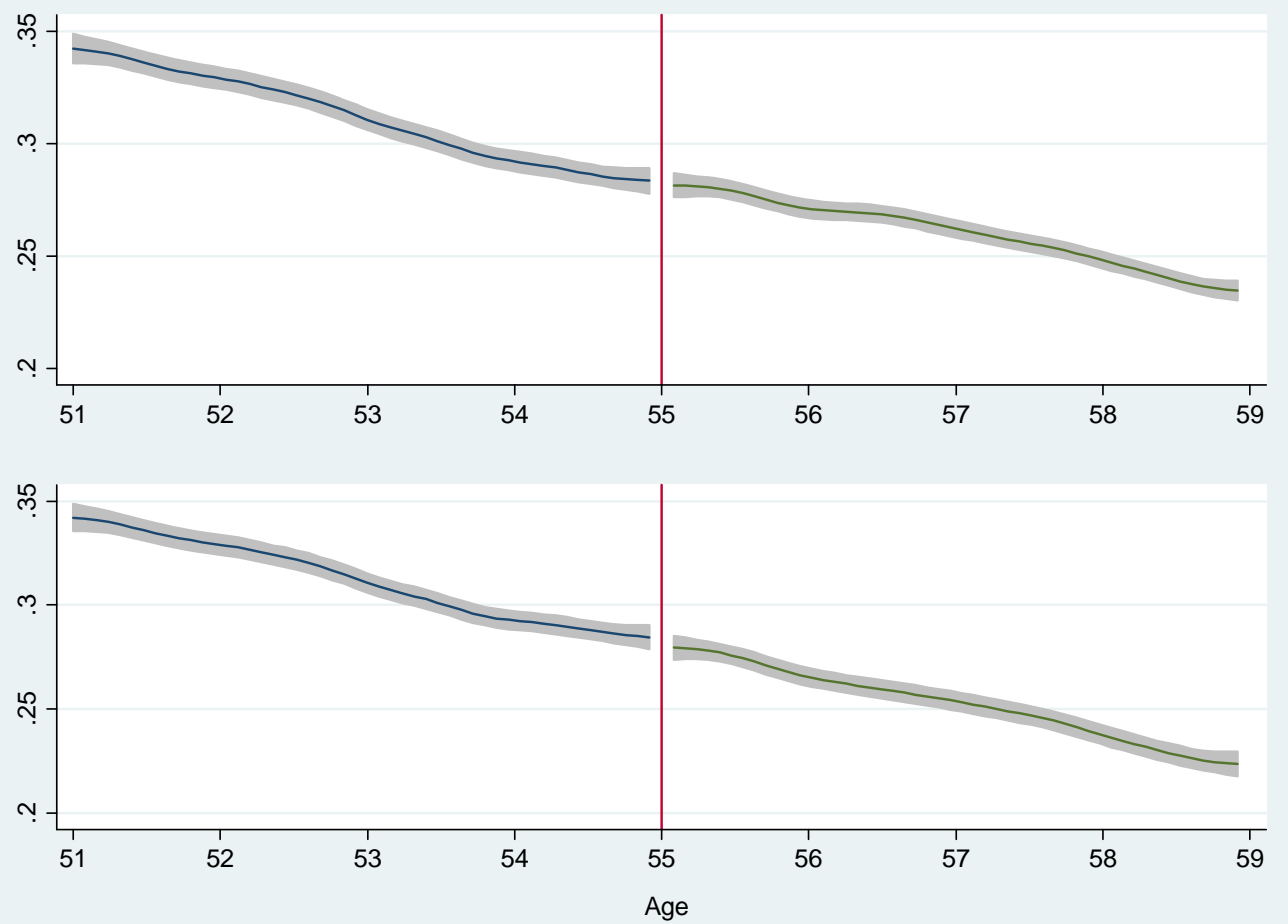

- Notes: The top graph is for the unrestricted sample and the bottom one when restricting to individuals who started claiming before age 55. The vertical red lines marks the limit at age 55 for eligibility to the DI increase. Local polynomials are smoothed by two months periods. Grey areas show the 95 percent confidence intervals around these polynomials. 
Figure 5: Age Started Claiming DI by Age

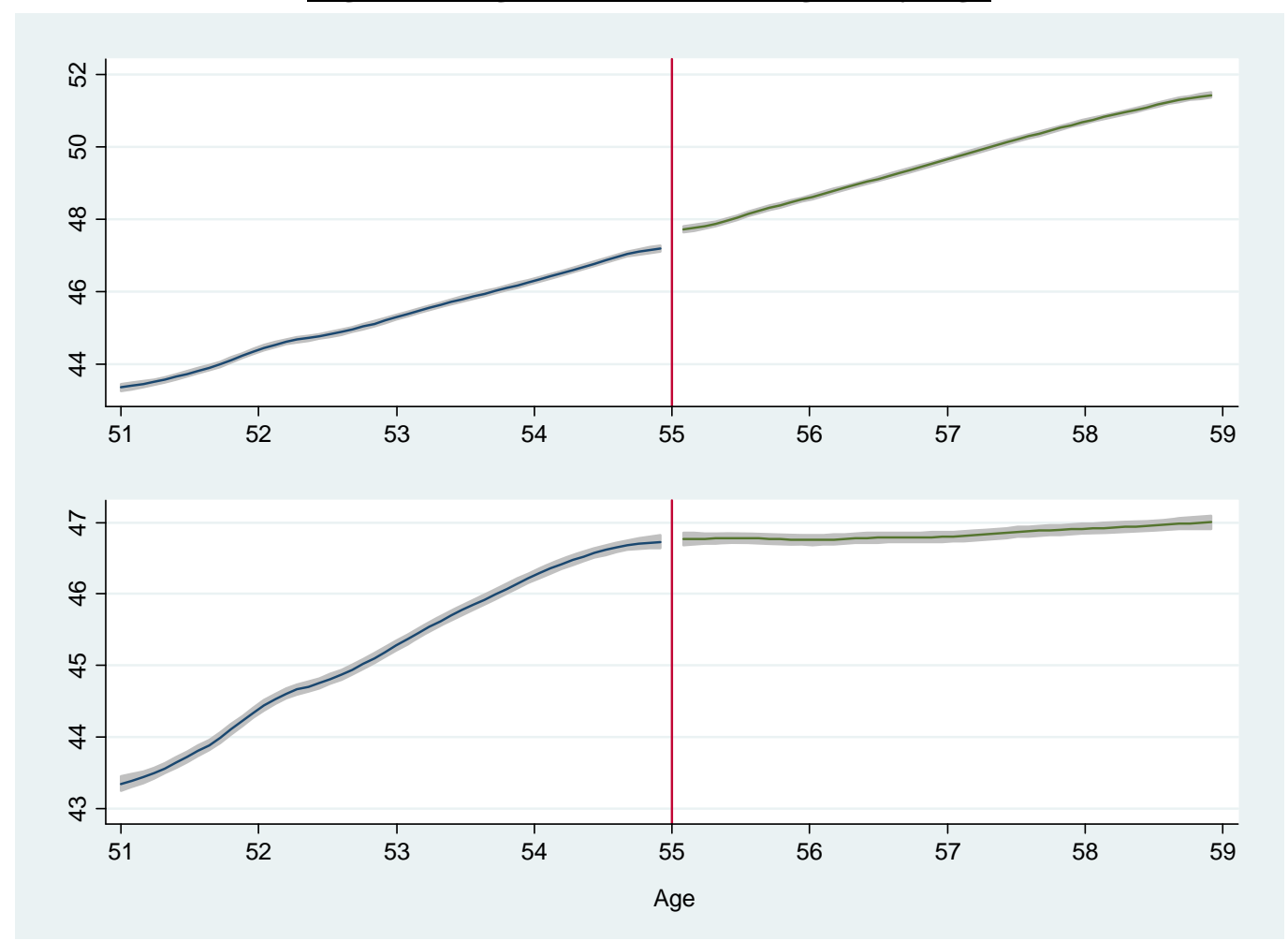

Notes: The top graph is for the unrestricted sample and the bottom one when restricting to individuals who started claiming before age 55. The vertical red lines marks the limit at age 55 for eligibility to the DI increase. Local polynomials are smoothed by two months periods. Grey areas show the 95 percent confidence intervals around these polynomials. 
Figure 6: Labour Market Participation of DI Claimants by Age
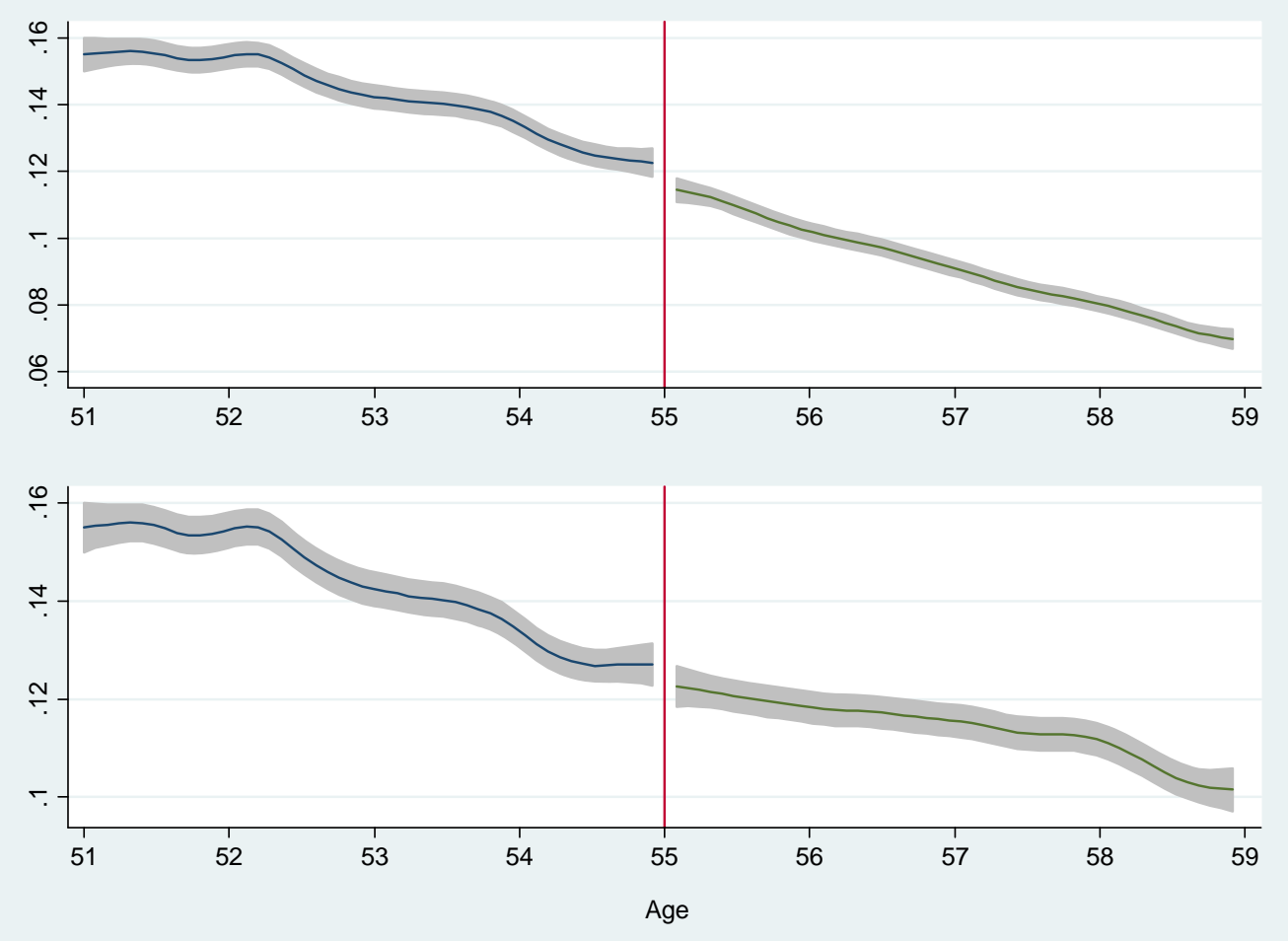

Notes: The top graph is for the unrestricted sample and the bottom one when restricting to individuals who started claiming before age 55. The vertical red lines marks the limit at age 55 for eligibility to the DI increase. Local polynomials are smoothed by two months periods. Grey areas show the 95 percent confidence intervals around these polynomials. 
Table 1 - DI Types in Spain:

Eligibility Criteria, Percentage of Claimants, and Replacement Rates

\begin{tabular}{lccc}
\hline & Partial Disability & Total Disability & Severe Disability \\
\cline { 2 - 4 } Main Eligibility Criteria & $\begin{array}{c}\text { Unable to perform } \\
\text { tasks of } \text { usual job }\end{array}$ & $\begin{array}{c}\text { Unable to perform } \\
\text { any kind of job }\end{array}$ & $\begin{array}{c}\text { Unable to perform } \\
\text { essential acts of life }\end{array}$ \\
$\begin{array}{l}\text { Percentage of } \\
\text { DI Claimants }\end{array}$ & $57 \%$ & $40 \%$ & $3 \%$ \\
$\begin{array}{l}\text { Replacement Rate } \\
\text { (\% Regulatory Base) }\end{array}$ & $\begin{array}{c}55 \% \text { or } \\
\text { \& low employment } \\
\text { probability }\end{array}$ & $100 \%$ & $150 \%$ \\
\hline
\end{tabular}


$\underline{\text { Table } 2 \text { - Descriptive Statistics of DI Claimants by Age and DII Receipt Status }}$

\begin{tabular}{|c|c|c|c|c|c|c|c|}
\hline \multirow[b]{3}{*}{$\begin{array}{l}\text { Disability Insurance } \\
\text { Increase (DII) }\end{array}$} & \multicolumn{3}{|c|}{ Receives or Not DII } & \multicolumn{4}{|c|}{ Ever or Never Receives DII } \\
\hline & $\begin{array}{l}\text { Aged } \\
51-54\end{array}$ & & & & & & \\
\hline & 0 & 0 & 1 & Never & Ever & Never & Ever \\
\hline $\begin{array}{l}\text { Average } \\
\text { Age }\end{array}$ & 53.1 & 56.9 & 57.1 & 52.9 & 53.3 & 57.0 & 57.1 \\
\hline $\begin{array}{l}\text { Proportion } \\
\text { Female }\end{array}$ & .296 & .289 & .315 & .278 & .314 & .292 & .312 \\
\hline $\begin{array}{l}\text { Secondary } \\
\text { Education }\end{array}$ & .310 & .252 & .263 & .337 & .283 & .251 & .263 \\
\hline $\begin{array}{l}\text { Age Started } \\
\text { Claiming }\end{array}$ & 45.4 & 47.8 & 50.4 & 44.5 & 46.3 & 47.8 & 50.5 \\
\hline $\begin{array}{l}\text { Proportion } \\
\text { Working }\end{array}$ & .142 & .223 & .017 & .238 & .043 & .232 & .026 \\
\hline $\begin{array}{l}\text { Number of } \\
\text { Observations }\end{array}$ & 262,760 & 128,691 & 231,777 & 133,172 & 129,588 & 112,485 & 247,983 \\
\hline
\end{tabular}




\begin{tabular}{|c|c|c|c|c|c|c|}
\hline & \multicolumn{6}{|c|}{$\begin{array}{c}\text { Dependent Variable: } \\
\text { Labour Market Participation }\end{array}$} \\
\hline & \multicolumn{2}{|c|}{ OLS } & \multicolumn{2}{|c|}{ DiD } & \multicolumn{2}{|c|}{ FE } \\
\hline & (1) & (2) & (3) & (4) & (5) & (6) \\
\hline $\begin{array}{l}\text { Disability Insurance } \\
\text { Increase (DII) }\end{array}$ & $\begin{array}{l}-.162 \\
(.005)\end{array}$ & $\begin{array}{l}-.194 \\
(.006)\end{array}$ & $\begin{array}{l}-.052 \\
(.006)\end{array}$ & $\begin{array}{l}-.081 \\
(.006)\end{array}$ & $\begin{array}{l}-.055 \\
(.003)\end{array}$ & $\begin{array}{l}-.056 \\
(.003)\end{array}$ \\
\hline 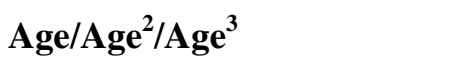 & Yes & Yes & Yes & Yes & Yes & Yes \\
\hline Unemployment Rate & Yes & Yes & Yes & Yes & Yes & Yes \\
\hline Year Dummies & Yes & Yes & Yes & Yes & Yes & Yes \\
\hline Individual Controls & Yes & Yes & Yes & Yes & No & No \\
\hline $\begin{array}{l}\text { Ever DII and Older than } \\
55 \text { Dummies }\end{array}$ & No & No & Yes & Yes & No & No \\
\hline Individual Fixed Effects & No & No & No & No & Yes & Yes \\
\hline $\begin{array}{l}\text { Restricted Sample (Started } \\
\text { Claiming before Age 55) }\end{array}$ & No & Yes & No & Yes & No & Yes \\
\hline Number of Observations & 623,228 & 510,325 & 623,228 & 510,325 & 623,288 & 510,325 \\
\hline
\end{tabular}

Note: Age is in month; Age $^{2}$ and Age $^{3}$ are respectively the square and cube of the difference from the mean Age. The Unemployment Rate is quarterly for the 51 Spanish administrative regions. The Individual Controls are: gender; secondary school completion; and age start claiming disability benefits. Robust standard errors clustered at the individual level are in parenthesis. All the coefficients reported are significant at the $5 \%$ level. 
Table 4: RD Results for Different Age

Windows around Eligibility Age Threshold

\begin{tabular}{|c|c|c|c|c|}
\hline & \multicolumn{4}{|c|}{$\begin{array}{l}\text { Estimation on Individuals } \\
\text { Aged } 55 \text { and }+/-4,3,2 \text { and } 1 \text { Year }\end{array}$} \\
\hline & $\begin{array}{c}\text { All } \\
\text { Ages }\end{array}$ & $\begin{array}{l}+/-3 \\
\text { Years }\end{array}$ & $\begin{array}{l}+/-2 \\
\text { Years }\end{array}$ & $\begin{array}{l}+/-1 \\
\text { Years }\end{array}$ \\
\hline $\begin{array}{l}\text { Discontinuity of DII Treatment Around } \\
\text { Threshold }\left(D I I^{+}-D I I\right)\end{array}$ & $\begin{array}{c}.612 \\
(.005)\end{array}$ & $\begin{array}{c}.595 \\
(.005)\end{array}$ & $\begin{array}{l}.567 \\
(.005)\end{array}$ & $\begin{array}{c}.517 \\
(.006)\end{array}$ \\
\hline $\begin{array}{l}\text { Difference in LMP Around } \\
\text { Threshold }\left(L M P^{+}-L M P^{-}\right)\end{array}$ & $\begin{array}{l}-.051 \\
(.003)\end{array}$ & $\begin{array}{l}-.041 \\
(.003)\end{array}$ & $\begin{array}{l}-.030 \\
(.003)\end{array}$ & $\begin{array}{l}-.016 \\
(.002)\end{array}$ \\
\hline $\begin{array}{l}\text { Estimated Effect of DII on LMP } \\
\text { Participation }\left(L M P^{+}-L M P^{-}\right) /\left(D I I^{+}-D I I^{-}\right)\end{array}$ & $\begin{array}{l}-.084 \\
(.005)\end{array}$ & $\begin{array}{l}-.070 \\
(.005)\end{array}$ & $\begin{array}{l}-.052 \\
(.005)\end{array}$ & $\begin{array}{l}-.031 \\
(.005)\end{array}$ \\
\hline Number of Observations & 632,228 & 463,438 & 306,460 & 151,904 \\
\hline
\end{tabular}

Note: The standard errors are in parenthesis. For the Estimated Effect of DII on LMP these are obtained following the Two Stage Least Square procedure suggested by Hahn et al (2001). Since some individuals are observed both before and after the threshold, we must account for within-individual correlation of the errors over time using clustered standard errors as highlighted by Lee and Lemieux (2010). All the coefficients reported are significant at the $5 \%$ level. 
Table 5: RD Results +/- 1 Year Around

Eligibility Age Threshold with Individual Controls

\begin{tabular}{|c|c|c|c|c|c|}
\hline \multirow[b]{2}{*}{$\begin{array}{l}\text { Discontinuity of DII Treatment Around } \\
\text { Threshold }\left(D I I^{+}-D I I\right)\end{array}$} & \multicolumn{5}{|c|}{$\begin{array}{l}\text { Estimation on Individuals } \\
\text { Aged } 55 \text { and +/- 1Year }\end{array}$} \\
\hline & $\begin{array}{l}.517 \\
(.006)\end{array}$ & $\begin{array}{l}.517 \\
(.006)\end{array}$ & $\begin{array}{l}.517 \\
(.006)\end{array}$ & $\begin{array}{l}.509 \\
(.006)\end{array}$ & $\begin{array}{l}.508 \\
(.006)\end{array}$ \\
\hline $\begin{array}{l}\text { Difference in LMP Around } \\
\text { Threshold }\left(L M P^{+}-L M P^{-}\right)\end{array}$ & $\begin{array}{l}-.016 \\
(.002)\end{array}$ & $\begin{array}{l}-.016 \\
(.002)\end{array}$ & $\begin{array}{l}-.015 \\
(.002)\end{array}$ & $\begin{array}{l}-.006 \\
(.002)\end{array}$ & $\begin{array}{l}-.006 \\
(.002)\end{array}$ \\
\hline $\begin{array}{l}\text { Estimated Effect of DII on LMP } \\
\text { Participation }\left(L M P^{+}-L M P^{-}\right) /\left(D I I^{+}-D I I\right)\end{array}$ & $\begin{array}{l}-.031 \\
(.005)\end{array}$ & $\begin{array}{l}-.030 \\
(.003)\end{array}$ & $\begin{array}{l}-.029 \\
(.005)\end{array}$ & $\begin{array}{l}-.011 \\
(.005)\end{array}$ & $\begin{array}{l}-.011 \\
(.005)\end{array}$ \\
\hline Proportion Female & No & Yes & Yes & Yes & Yes \\
\hline Proportion with Secondary Education & No & No & Yes & Yes & Yes \\
\hline Age Started Claiming Disability & No & No & No & Yes & Yes \\
\hline Year Dummies & No & No & No & No & Yes \\
\hline Number of Observations & 151,904 & 151,904 & 151,904 & 151,904 & 151,904 \\
\hline
\end{tabular}

Note: The standard errors are in parenthesis. For the Estimated Effect of DII on LMP these are obtained following the Two Stage Least Square procedure suggested by Hahn et al (2001). Since some individuals are observed both before and after the threshold, we must account for within-individual correlation of the errors over time using clustered standard errors as highlighted by Lee and Lemieux (2010). All the coefficients reported are significant at the $5 \%$ level. 
Table 6: RD Results +/- 1 Year Around

Eligibility Age Threshold with Individual Controls

for Individuals who Started Claiming before Age 55

\begin{tabular}{|c|c|c|c|c|c|}
\hline \multirow[b]{2}{*}{$\begin{array}{l}\text { Discontinuity of DII Treatment Around } \\
\text { Threshold }\left(D I I^{+}-D I I\right)\end{array}$} & \multicolumn{5}{|c|}{$\begin{array}{l}\text { Estimation on Individuals } \\
\text { Aged } 55 \text { and +/- 1Year }\end{array}$} \\
\hline & $\begin{array}{l}.499 \\
(.006)\end{array}$ & $\begin{array}{c}.499 \\
(.006)\end{array}$ & $\begin{array}{c}.499 \\
(.006)\end{array}$ & $\begin{array}{c}.498 \\
(.006)\end{array}$ & $\begin{array}{c}.498 \\
(.006)\end{array}$ \\
\hline $\begin{array}{l}\text { Difference in } L M P \text { Around } \\
\text { Threshold }\left(L M P^{+}-L M P^{-}\right)\end{array}$ & $\begin{array}{l}-.007 \\
(.002)\end{array}$ & $\begin{array}{l}-.007 \\
(.002)\end{array}$ & $\begin{array}{l}-.007 \\
(.002)\end{array}$ & $\begin{array}{l}-.005 \\
(.002)\end{array}$ & $\begin{array}{l}-.005 \\
(.002)\end{array}$ \\
\hline $\begin{array}{l}\text { Estimated Effect of DII on LMP } \\
\text { Participation }\left(L M P^{+}-L M P^{-}\right) /\left(D I I^{+}-D I I\right)\end{array}$ & $\begin{array}{l}-.014 \\
(.005)\end{array}$ & $\begin{array}{l}-.015 \\
(.005)\end{array}$ & $\begin{array}{l}-.013 \\
(.005)\end{array}$ & $\begin{array}{l}-.010 \\
(.005)\end{array}$ & $\begin{array}{l}-.010 \\
(.005)\end{array}$ \\
\hline Proportion Female & No & Yes & Yes & Yes & Yes \\
\hline Proportion with Secondary Education & No & No & Yes & Yes & Yes \\
\hline Age Started Claiming Disability & No & No & No & Yes & Yes \\
\hline Year Dummies & No & No & No & No & Yes \\
\hline Number of Observations & 138,121 & 138,121 & 138,121 & 138,121 & 138,121 \\
\hline
\end{tabular}

Note: The standard errors are in parenthesis. For the Estimated Effect of DII on LMP these are obtained following the Two Stage Least Square procedure suggested by Hahn et al (2001). Since some individuals are observed both before and after the threshold, we must account for within-individual correlation of the errors over time using clustered standard errors as highlighted by Lee and Lemieux (2010). All the coefficients reported are significant at the $5 \%$ level. 
Table 7: Placebo Reduced Forms of Changes in LMP with no DII Partial Disability Claimants (Age 54) and Total Disability Claimants (Age 55)

$$
\text { Dependent Variable }=\text { LMP Change }
$$

(2)

$\begin{array}{lc}\text { Placebo DII for Partial Disability } & -.004 \\ \text { Claimants at Age } 54 \text { (+/- } 1 \text { Year) } & (.003)\end{array}$

Placebo DII for Total Disability

Claimants at Age 55 (+/- 1 Year)

Proportion Female

Yes Yes

Proportion with Qualification

Yes

Yes

Age Started Claiming Disability

Yes

Yes

Year Dummies

Yes

Yes

Number of Observations

140,681

114,308

Note: Robust standard errors clustered at the individual level are in parenthesis. 


\section{Appendix:}

Table A1. Requirements for DI eligibility (same for partial, total, and severe disability)

\begin{tabular}{llll}
\hline & \multicolumn{1}{c}{ Common Illness } & $\begin{array}{l}\text { Work-unrelated } \\
\text { Accident }\end{array}$ & $\begin{array}{l}\text { Working-accident or } \\
\text { Professional Illness }\end{array}$ \\
\cline { 2 - 4 } $\begin{array}{l}\text { Minimum } \\
\text { Contribution }\end{array}$ & $\begin{array}{l}\text { 1/3 of the time between } \\
\text { turning } 20 \text { years old } \\
\text { and becoming disabled. } \\
\text { Minimum required of } 5 \\
\text { years contribution*. }\end{array}$ & \multicolumn{1}{c}{ No contributory requirement. } \\
$\begin{array}{l}\text { Regulatory } \\
\text { Base }\end{array}$ & $\begin{array}{l}\text { Average wage in the } \\
\text { last } 8 \text { years of work. }\end{array}$ & $\begin{array}{l}\text { Average wage over a } \\
\text { period of 24 consecutive } \\
\text { months chosen from the } \\
\text { last 7 years of work. }\end{array}$ & $\begin{array}{l}\text { Average wage in the } \\
\text { last year of work. }\end{array}$ \\
\hline
\end{tabular}

\footnotetext{
* If the individual is younger than 31 when becoming disabled, the requirement is to have contributed for $1 / 3$ of the time between age 16 and the appearance of the disabling condition with no minimum of years required
} 
$\underline{\text { Table A2. Minimum and maximum amounts for disability benefits }}$

\begin{tabular}{|c|c|c|c|c|c|c|}
\hline \multirow[b]{2}{*}{$\begin{array}{l}\text { Minimum } \\
\text { Amount } \\
\text { guaranteed }\end{array}$} & \multicolumn{2}{|c|}{ Total } & \multicolumn{2}{|c|}{ Partial (ages 60-64) } & \multicolumn{2}{|c|}{ Partial (age $<60)$} \\
\hline & Monthly & Annual & Monthly & Annual & Monthly & Annual \\
\hline $\begin{array}{l}\text { With } \\
\text { dependents }\end{array}$ & 742 & 10388 & 695,4 & 9735,6 & 374 & 5236 \\
\hline $\begin{array}{l}\text { Without } \\
\text { dependents }\end{array}$ & 601,4 & 8419,6 & 562,5 & 7875 & 374 & 5236 \\
\hline $\begin{array}{l}\text { With partner } \\
\text { but not } \\
\text { dependent }\end{array}$ & 570,4 & 7985,6 & 531,5 & 7441 & $\begin{array}{l}55 \% \text { of } \\
\text { minimum } \\
\text { regulatory } \\
\text { base }\end{array}$ & $\begin{array}{l}55 \% \text { of } \\
\text { minimum } \\
\text { regulatory } \\
\text { base }\end{array}$ \\
\hline $\begin{array}{l}\text { Maximum } \\
\text { amount }\end{array}$ & \multicolumn{6}{|c|}{2497,91 euros/month or 34970,74 euros/annually } \\
\hline \multicolumn{7}{|c|}{$\begin{array}{l}\text { In order for this minimum amounts to be applied, the individual must not earn more than } 6923,9 \text { (without } \\
\text { dependents) or } 8076,8 \text { (with dependents) annually (from a source different from the benefit). If the } \\
\text { individual earns more than this threshold, then no minimum quantity is applied and the person receives } \\
\text { the pension that is derived from the calculations for his/her case. }\end{array}$} \\
\hline
\end{tabular}

